\title{
The Greek suffix -ozos
}

\section{A Case Study in Loan Suffixation}

\author{
Georgia Katsouda
}

Research Centre for Modern Greek Dialects, Academy of Athens katsouda@academyofathens.gr

\begin{abstract}
This paper offers a morphological analysis of the borrowed derivational suffix -ółos [ózos], used in both a number of Modern Greek (MGr) dialects and in Standard Modern Greek (SMGr). It draws on an extensive corpus to examine the suffix from both a synchronic and a diachronic perspective. Our diachronic analysis emphasizes the geographical distribution, the etymological provenance of the suffix, and the loan accommodation strategies employed in various MGr dialects, thus providing some interesting etymological findings regarding the lexical stock of Modern Greek (Standard and dialects). Our synchronic analysis focuses on the stem categories with which the suffix combines and accounts for the phonological, morphological, and syntactic constraints that function during the derivational process.
\end{abstract}

\section{Keywords}

loanword - loan suffixation - borrowable - donor language - recipient language accommodation strategy - constraint

\section{Introduction}

This paper provides a morphological analysis of the borrowed derivational suffix -ó̧os [ózos], which has not until now been systematically investigated. The suffix is used in a number of Modern Greek (MGr) dialects, mainly to form adjectives, as shown in (1): 


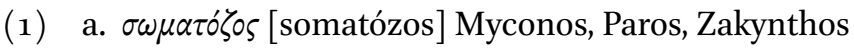
'stout'

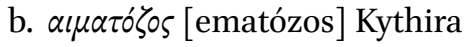
'scarlet'

Here, in the present article, we draw on an extensive corpus to examine the suffix -ó̧os [ózos] from both a synchronic and a diachronic perspective. Our diachronic analysis focuses on the geographical distribution and the etymological provenance of the suffix -ózos and on loan accommodation strategies employed in the various MGr dialects (Haspelmath 2008; AnastasiadiSymeonidi 1994). We find parallels for -ózos in other suffixes, such as -(ı)́́p [(i)áris] and -ílos [ísços] and then offer some interesting primary observations. Our synchronic analysis describes the stem categories with which the suffix combines and so accounts for the phonological, morphological, and syntactic constraints that are found to be operative in the derivational process (see Ralli 2005: 154-157).

The paper attempts above all to shed light on a corpus of very interesting and hitherto unknown dialectal data and is an example of contemporary research on the etymology of the lexical stock of the MGr dialects. It also offers a case-study of a specific suffix and so attempts to confirm to a large extent the generalizations so far established by modern cross-linguistic research on language change driven by contact.

The corpus of our dialectal data is derived from the five volumes of the Historical Dictionary of Modern Greek (ILNE) (1933-1989) and from the unpublished Archive of the Research Centre for Modern Greek Dialects of the Academy of Athens (Archive of KENDI-ILNE), which contains a considerable quantity of excerpted manuscript collections of oral dialectal speech and written sources, in the form of dictionaries, glossaries, and so on, accompanied by retrievable metadata.

Here we should note that our etymological suggestions for all dialectal forms rest on the phonological, morphological, semantic, and space-time criteria proposed in recent literature (see Moisiadis 2005, Katsouda 2012: 858). More particularly, for the etymology of any dialectal form, our analysis takes account of a) the related phonological processes and developments in Greek and in Romance, b) the formal morphological similarity or difference between the Greek forms and corresponding Romance forms, c) semantic similarities and differences between cognate Romance forms and d) the socio-historical context of each Modern Greek-speaking area. 
The duration and the intensity of contact between the donor and the recipient language determines the type of structures borrowed, a factor expressed in hierarchical terms in Thomason \& Kaufman's borrowability scale (1988: 74-75). Thus a closer look at the socio-historical conditions informing contact between Greek and Romance is necessary.

In what follows here we offer a short sketch of Greek history during the medieval and early modern period. We focus on areas and conditions dictating language contact so as to set the specific borrowing process we are examining here in a wider context. Further details can be found in Browning (1999) and Horrocks (2010).

The battle of Manzikert (1071) was a landmark in the history of the late Byzantine Empire since the Seljuk Turks (and the later Ottoman Turks) conquered large parts of Asia Minor, thus triggering the decay of the Byzantine empire. The decline accelerated with the capture by the Crusaders of Constantinople in 1204, an event that gradually brought many Greek-speaking areas under the control of Romance-speaking conquerors via the foundation of "western-ruled states" (Markopoulos 2014: 9o). Rhodes came under the military rule of the monastic order, the Knights of Saint John, in 1310 and remained there until 1522. Cyprus was held by the Frankish Lusignan family from 1191 to 1489, this being followed by the Venetian occupation, which ended in 1571. The Duchy of Athens (1205-1458) was held by a Burgundian knight who had arrived with the Fourth Crusade, Otto de la Roche, to pass in 1388 into the possession of the Florentine Acciaiuoli family. The Venetian Sanudo family founded the Duchy of Naxos (1207-1579), which included most of the Aegean Islands, in particular the Cyclades. Many of the islands of the Aegean remained for centuries in the hands of the Venetians, cases in point being Myconos (12041390), Tinos (1204-1715), Naxos (1207-1566), and Syros (1204-1579). Moreover, the Lordship of Negroponte, which included Euboea, was subject to Venetian influence (1205-1470). Chios was occupied by Genoese (1329-1566), while Lesbos was held by the Genovese Gattelusi family (1355-1462). The Venetians held Crete for more than four centuries, from 1211 till 1669, at which time the Ottoman occupation began. In the Ionian Islands, the Venetian occupation was lengthy, lasting sometimes for more than six centuries, namely from 1207 to 1797 . Such longevity of occupation can be seen in the cases of Corfu and Paxoi (1207-1214 and 1386-1797), Lefkada, (1684-1797), Zakynthos (1479-1797), Cephalonia and Ithaca (1500-1797), and Cythera (1207-1797). The Venetians controlled many Peloponnesian areas, such as Methoni and Koroni (12071500), and many areas of Epirus, such as Parga (1401-1797), Preveza (1717-1797), 
and of Etoloacarnania, such as Nafpaktos (1407-1540) and Vonitsa (1684-1797) (see Savvidis 2003: 187-209, Markopoulos 2012: 425-428, Markopoulos 2014: 90).

Clearly, the co-existence of Greeks and Romance speakers did not possess the same duration, intensity and features in all these areas. However, as Markopoulos observes (2014: 90), despite differences, the co-existence of two communities makes language contact inevitable, which implies the existence of bilingualism, full or partial.

In some cases, full bilingualism in Greek occurs in areas where Romance minorities mingled with the local Greek population. This happened, for example, in Cyprus by the 15th and in Crete by the 17th c. (Markopoulos 2014: 91). On the other hand, bilingualism in Romance was for some Greek speakers a means of upward social mobility. Another important cause of full bilingualism was intermarriage, very common in Crete and Cyprus, for example. Finally, partial bilingualism is to be explained as result of Romance-Greek trade relations in Mediterranean ports, which were obviously facilitated through the use of a common language (Markopoulos 2014: 91).

Bilingualism was of course mainly an urban matter (see Terkourafi 2005, Manolessou 2008, Markopoulos 2012): Romance speakers, for instance, were to be found in trade ports and only rarely in the countryside (Markopoulos 2014: 91). A typical example of this is the case of Cythera in Venetian times, where edicts were usually left untranslated for the upper class, who lived in the Fortezza and who understood the Venetian/ Italian language. On the other hand, the peasants learned of the content of every edict via interpreters, who translated them "in idioma greco a parola per parola" (Maltezou 2008: 134, Leontsinis 2005: 470, 563-564).

Although the suffix -oso is very productive in all Romance languages, the Latin -ōsus (Ernout 1949) and the Italian suffix -oso (Magni 2001) have been the most deeply studied. Notably, the suffix belongs to the very few patrimonial suffixes transmitted grammatically and semantically intact from Latin into Roman languages (Pharies 2015: 1857).

A main syntactic constraint is that, prototypically, both the Latin and the Italian suffix are added to nominal stems (Magni 2001: 4-5), e.g.,

(2) a. glori(a) 'glory' + -ōsus > Lat. gloriōsus 'glorious' [[glori(a $\left.)_{\text {Noun }}\right]$ -ōsus $]_{\text {Adj. }}$ 
b. carn(e) 'meat' + -oso > carnoso (14th c.) 'who has a lot of meat' $\left[\left[\operatorname{carn}(\mathrm{e})_{\text {Noun }}\right] \text {-oso }\right]_{\text {Adj. }}$

c. premur(a) 'rush' + -oso > premuroso (17th c.) 'who is in a great rush' $\left[\left[\operatorname{premur}(\mathrm{a})_{\text {Noun }}\right]-\text { oso }\right]_{\text {Adj. }}$

However, Montermini (2001) notes that verbal derivatives in -oso are also attested, which, in the view of Ernout (1949: 77), are rare later formations, e.g.,

(3) pens(are) 'to worry' + -oso > pensoso 'who worries a lot' [[pens(are $\left.)_{\text {Verb }}\right]$ - oso $]_{\text {Adj. }}$

More specifically, the nominal stems onto which the suffixes -ōsus/ -oso are added, belong to nouns, common-concrete or abstract—and inanimate (Scalise 1994: 99), although there are new formations based on the stem of animate nouns (Magni 2001: 4-6), ${ }^{1}$ e.g.,

(4) $\operatorname{serp}(e)$ 'serpent' + -oso > serposo 'full of serpents' [[serp(e $)_{\text {Noun.Anim. }}$ ] - oso $]_{\text {Adj }}$.

The properties of the nominal stems can therefore be described as follows:

(5) $\left[[]_{\text {Noun }}\right]-\bar{o}$ sus/-oso $]_{\text {Adj. }}$

[+ com.]

[abstr.]

[anim.]

In the view of Magni (2001: 12-13), adjectives formed with -ōsus/-oso have the meaning "who/ what possesses a quantity or quality $\mathrm{x}$ ", when $\mathrm{x}$ is that which the nominal stem expresses (see also Rohlfs 1969: 441, Lehmann 1977²: 231, Tekavčić 1980: 77). In addition to the prototypical meaning "full of $x$ ", the suffix has also some more peripheral meanings, such as "who does X", "who/ what is characterized by X", "who/ what is similar to X" (Magni 2001: 8).

Latin- and Italian-suffixed adjectives have pejorative connotations (Magni 2001: 14, 18). Ernout (1949: 80) observes that a large number of medical terms were formed with -ōsus. The suffix was added to nominal stems of nouns

1 Magni (2001: 4) notes that the suffix -ōsus/-oso is not added to nominal stems of color and proper names. There are no formations such as *verdoso (< verde 'green') or Giannoso (< Gianni 'proper name'). 
denoting illness, a specific harm or the affected part of the body (e.g., morbōsus 'morbid' < morbus 'disease').

Another interesting point is that both the Latin and the Italian suffix form adjectives which may have both agent and patient thematic roles, i.e., can be analyzed in terms of either active or passive verb phrases. For example, the Latin invidiōsus can be interpreted in two ways (Magni 2001: 17):

a. invidiōsus [+active] '(one) who is jealous'

or

b. invidiōsus [+passive] '(one) who is envied (i.e., enviable)'

As for the referent, it can be either animate or inanimate (Magni 2001: 18). Thus the presumed referent in $(7 \mathrm{a})$ is animate, while that in $(7 \mathrm{~b})$ is inanimate:

(7) a. pauroso [+anim.] 'who is afraid'

or

b. pauroso [+inanim.] 'what provokes fear'

To conclude: the suffix -ōsus/-oso forms adjectives that refer to persons or objects, meaning, in either a positive or pejorative manner, "who/ what possesses a quantity or quality $\mathrm{X}$ ", when $\mathrm{x}$ is that which the nominal stem denotes. The Latin suffix occurs in many Romance languages with the same function, as for example in French (Ahn 1994) and Spanish (Prieto Prieto 2002: 1580). Finally, one may note that the suffix is productive in English, too. The suffix, borrowed by English sometime after the 15th century, has two forms, the form -ose being employed in two-syllable words and -ous in polysyllabics (Miller 2012: 166; See also Lass 1999: 3 vol., 403). 


\subsection{The First Evidence}

Latin words in -ōsus were borrowed into Greek during medieval times (5/6th c. $-13^{\text {th }}$ c.), as can be seen in (8):

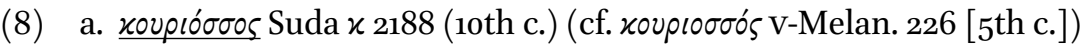
'officer responsible for the invigilation of travelers'

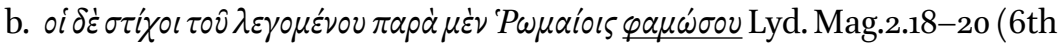
c.) 'the lyrics of the famoso [libel], so-called by the Romans'

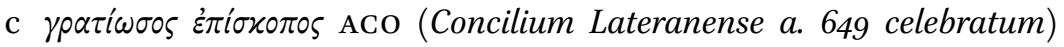
1.6.15 (7th c.) 'respected bishop'

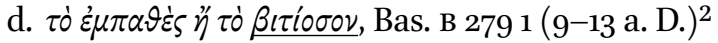
'passionate or defective'

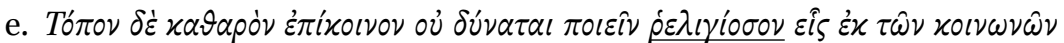
Basilica, Scholia in Basilicorum libros I-XI, 12.2(CA). 6. 9. (A.D.9-13) 'None of the communicants can change a clean shared place into a pious one'

Such cases are few, probably because of the scarcity of textual sources from the 8th and gth century, which therefore does not allow one to form a complete picture of the later stages of early Medieval Greek (see Holton \& Manolessou 2010: $542-543$ ). Nevertheless, a few points can be made. Forms such as $\beta i \tau i ́ 0-$

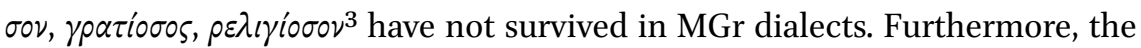
majority of the loanwords in -oso imported in MGr dialects mentioned below do not have a corresponding Latin form.

It is also to be noted that the meaning of the Latin loanwords above is not to be found in any of the MGr dialects. For example, the loanword xovpióros, 'officer responsible for the invigilation of travelers', retains the core meaning of the Latin word curiōsus 'who oversees something'. The type curioso, meaning 'who wants to know', appears at the end of the 14th c. (Cortelazzo \& Zolli 1999²).

2 For the examples (8) a., c. and d., see Trapp (1994-), for (8) b. and e. see Thesaurus Linguae Graecae (TLG).

3 Latin loanwords adopted into Greek followed the ancient Greek accentuation rules, rather than the corresponding Latin rules (see Kramer 1998: 133-134). This explains why adjectives

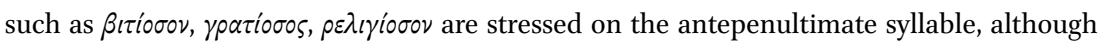
the vowel -o- in the Latin suffix -ōsus is long. 
Thus curioso ('curious') was loaned from Venetian into MGr dialects with this meaning after the 14th c. (see Boerio 1856).

Consequently, if one employs morphological and semantic criteria, ${ }^{4}$ it can be argued that the loan suffix -oso was taken into MGr dialects through Venetian and Italian loanwords, rather than through Latin loanwords, as we will demonstrate below.

Greek texts that document early appearances of loanwords in -ózos are rare. The following instances may be quoted:

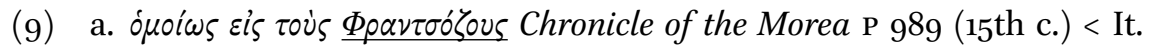
franzoso

'similarly in the French'

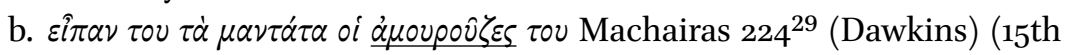
c. $)^{5}<$ middle French amoureux

'his lovers told him the news'

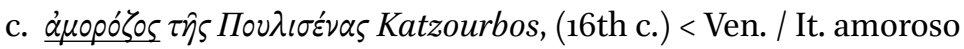
'Poulisena's lover'

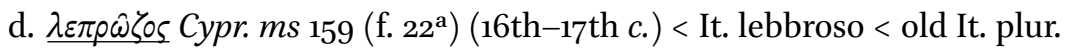
leprosy

'leper'

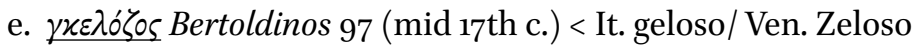
'jealous'

These loanwords, dating from the 15 th, 16 th, and $17^{\text {th }}$ c., survive in MGr dialects,

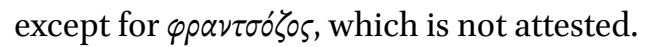

\subsection{The Donor Language}

The donor language of the majority of the loanwords in -oso in MGr dialects is mainly the Venetian dialect and the Italian language. Of course these are not the only donor languages involved because, as we mentioned in section 3, after the capture of Constantinople in 1204, Greek-speaking areas fell under Romance domination, both Venetian and Catalan, Genoese, Provençal, Frankish or Lombard. ${ }^{6}$ For example,

4 Cf. Anastasiadi-Symeonidi (1994: 6o) who argues on the basis of semantic criteria that the loanword parking was inserted in SMGr from French, rather than directly from English.

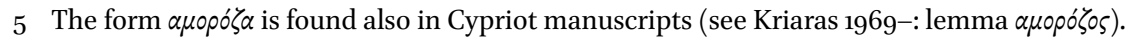

6 On the influence of French in Cypriot Greek during the Lusignan period in particular, see Davy \& Panagiotou 2000. 
(10) apovpoú Yos [amurúzos]

'lover'

was borrowed into the Cypriot dialect via the Middle French (< Middle Fr. amoureux)

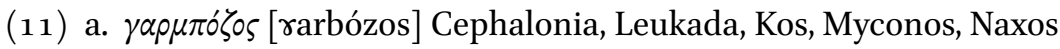

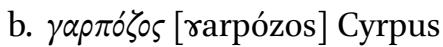
'jaunty, dandy, flirtatious'

Both (11) a. and b. derive from dialectal Italian garboso. The adjective is also attested in the Spanish language at the beginning of 18th c. (1702) (see Corominas 1970: s.v. garbo).

Thus different donor languages may often be responsible for related loan dialectal forms. In many cases, it is easy to spot the Venetian dialect as the donor language, as the forms in the recipient dialects preserve that of the Venetian word, which differs from the Standard Italian form. For example:

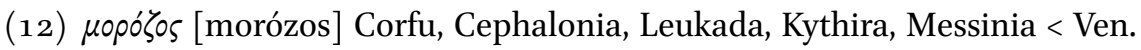
moroso

'lover'

contrasting with the It. cognate form amoroso.

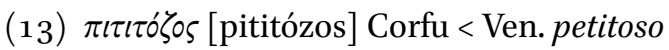
'selective in food'

contrasting with the It. cognate form appetitoso. ${ }^{7}$

Unfortunately, chronological evidence concerning the appearance of these forms in the Venetian dialect is available for only some of the loanwords located. ${ }^{8}$

In other cases, on the other hand, it is difficult to decide whether Standard Italian or Venetian was the donor language, for two reasons, namely:

a) the loanword appears in the same form in both varieties. For example,

7 On all the Venetian adjectives in -oso see Boerio (1856).

8 On the attested Venetian words of the 16th c., see Cortelazzo (2007). 


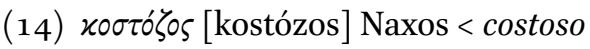
'expensive'

attested both in Venetian and in Standard Italian, and

b) the loanword is not attested in Venetian, although the noun in question, on the stem of which the production of the adjective was based, does exist; for example,

\section{(15) $\alpha \beta \alpha \nu \tau \alpha \gamma \varkappa ı o ́ \zeta o s ~[a v a n t a j o ́ z o s] ~ L e u k a d a<$ Ven. *avantazoso} 'advantageous'

The adjective may have existed in Venetian, since the noun avantazo 'advantage' exists in Venetian, and the corresponding forms of the Italian noun and adjective are vantaggio and vantaggioso respectively. Of course, however, one should bear in mind that Standard Italian was adopted as the official language by Venice long before the unity of Italy in the second half of the 19th c. (Fanciullo 2008). So, often it is not easy to discern whether a loanword was borrowed from Venetian or from Standard Italian.

Because chronologically based data is generally lacking, one has to use the first appearance of the adjective in -oso in the donor language as a terminus post quem for insertion of the loanword in MGr dialects. In the Index below, the tables display the loan adjectives in -ózos found both in MGr dialects and in Standard MGr (SMGr). They give every dialectal form followed by its geographic distribution, the meanings of all accommodated Greek forms and, lastly, the postulated donor language. The data is divided in groups formulated according to the century of the first appearance of the word in question (Cortelazzo \& Zolli $\left.1999^{2}\right)$.

\subsection{Loanwords in -ózos in MGr Dialects}

We identified a total of 39 loanwords ending in -ózos. Nine entered MGr dialects after 13th c. (see Index Ia), 12 after the 14th c. (see Index Ib), two after the 15th c. (see Index Ic), six after the 16th c. (see Index Id), six after the 17th c. (see Index Ie), three after the the 18th c. (see Index If), and two after the 19th c. (see Index Ig).

The majority of loanwords attested in the donor language in the 13th and 14th

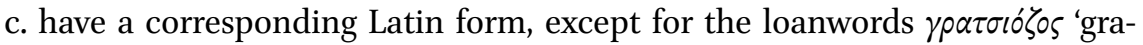

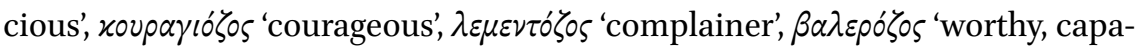

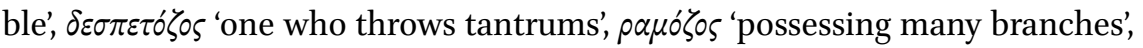

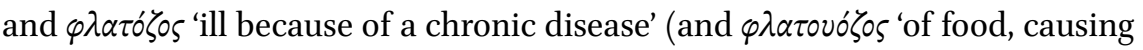


TABLE 1 Geographical distribution of the 39 loanwords in -ózos

\begin{tabular}{|c|c|c|c|}
\hline Place & $\begin{array}{c}\text { Loanwords } \\
\text { (total 39) }\end{array}$ & Place & $\begin{array}{c}\text { Loanwords } \\
\text { (total 39) }\end{array}$ \\
\hline
\end{tabular}

\begin{tabular}{lllr}
\hline Sporades & 1 & Epirus (Preveza, Ioannina etc) & 3 \\
Bithynia & 1 & Ionia & 1 \\
Chalcidice & 1 & Ionian islands & 25 \\
Chios & 1 & Kos & 1 \\
Crete & 1 & Megara & 1 \\
Cyclades & 7 & Peloponnese (Messinia, Mani) & 3 \\
Cyprus & 7 & Propontis & 1 \\
Etoloacarnania & 2 & Samos & 2 \\
Euboia & 2 & & \\
\hline
\end{tabular}

gas'), although, as already stated in the previous section, the meaning of the Greek loanwords may be very different. On the other hand, all the adjectives

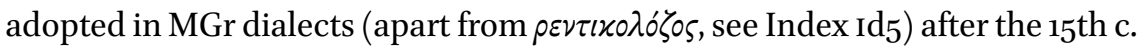
are formations without a corresponding form in Latin (see Index Ic, Id 1-4, 6, Ie ${ }_{1-5}$, If, and Ig). Taken together, these two facts, that is, semantic differentiation from Latin and the absence of a Latin original after the $15^{\text {th }}$ c., further reinforce the assumption that the language from which the words were borrowed was Italian or Venetian, rather than Latin.

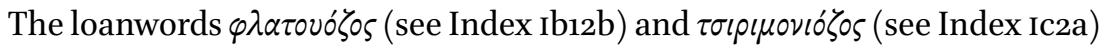
belong to the rare cases listed in dictionaries of the 19th c., for example, in that of Byzantios $\left(1874^{3}\right)$ and that of Peridis (1878) respectively.

As is evident from Table 1 above, we identified just one loanword in -ózos in an area covering the Sporades, Bithynia, the Chalcidice, Ionia, Kos, Megara, Propontis, and even Crete. The Cyclades, Cyprus, South Peloponnese (Mani, Messinia), and above all the Ionian Islands are the areas where most of the loanwords mentioned above, that is 25 out of 39 , are attested.

Note that the recipient dialects of the bulk of these loanwords are spoken in regions where there was intense language contact with Venetian and Italian due to historical and geographic reasons connected mainly with the Venetian supremacy, which in many areas, as we have noted, lasted more than three centuries, and with the proximity of these areas to the Italian peninsula.

With regard to the accommodation strategy, Haspelmath (2008: 8) comments that when dealing with borrowed adjectives, note should be taken of both donor and the recipient systems. Structural properties of both the donor 
and the recipient language are extremely important in the choice of borrowing strategy to be followed (Anastasiadi-Symeonidi 1994, Ralli 2011: 191; cf. Ralli 2012; see also Meillet 1921: 82, McMahon 1994: 204). As for the -ózos suffix, since Greek and Romance belong to the same linguistic family, they therefore share many structural similarities, such as derivational and inflectional strategies. Furthermore, Greek and Italian have very similar phonological systems, a feature that facilitates the integration of linguistic material from one language into another.

In particular, Anastasiadi-Symeonidi (1994: 195) notes that, during the stage of secondary morphological adaption, the final element of the stem and the position where stress is placed play a crucial role in the accommodation of a loan noun or adjective to an inflectional paradigm of the recipient language. The phonological similarity of the final vowel between the loanwords in -oso with the Greek nominal stems in -o facilitates their adoption in Greek. They

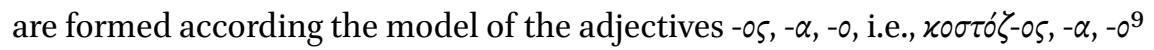
[kostózos/ kostóza/ kostózo] // wpai-os, - $\alpha,-0$ [oréos/ oréa/ oréo]. At this point, it should be noted that in many dialectal varieties the neuter gender is formed with the suffix -oz-o and not -oz-iko, although in SMGr the predominant suffix is -óz-iko. The prevalence of this suffix -óz-íko, óz-ici, -óz-iko can be accounted for, if one recalls that the majority of the adjectives in -ózos possess mainly a

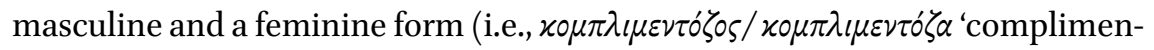
tary'), as their referent does [+animate]. These forms can be substantivized by conversion and afterwards may form a new adjective with the suffix -ikos (cf. the formation of the neuter of adjectives in -(i)áris, see Anastasiadi-Symeonidi 2000: 68):

$\left.\left[\left[[\text { komplimentózos }]_{\text {Adj. Conv. }}\right]_{\text {Noun }}-\mathrm{ikos}\right]_{\text {suffix }}\right]_{\text {Adj. }}$

In rare cases, a masculine is formed in $-\eta \varsigma$ such as

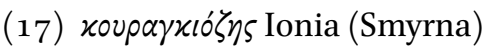 \\ 'who has courage'}

probably analogically formed to the adj. in $-i s,-a<-\eta \varsigma,-\alpha\rangle: \zeta \eta \lambda ı \alpha$ p- $\eta \varsigma$ [ziKáris] /

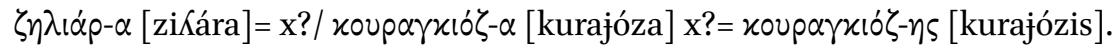

Furthermore, the loanwords in question underwent phonetic change characteristic of specific varieties of MGr. For example,

9 The form also occurs in the literary works of the Aivaliot Fotis Kontoglou (2012: 277) "M $\pi \alpha \rho$ -

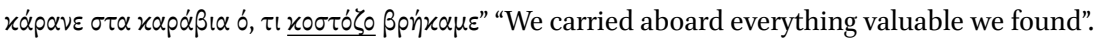


(18) furioso yovpió̧ous [furjúzus] in northern MGr dialects due to vowel raising 'furious'

All loanwords function as adjectives in the recipient language, except for the

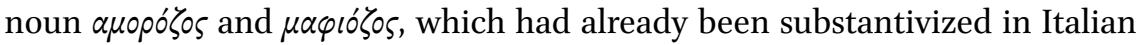
and Venetian.

During subsequent stages, adapted loanwords were combined with Greek

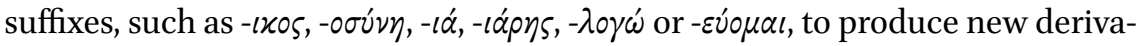
tives or compounds such as:

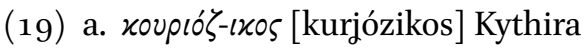
'curious'

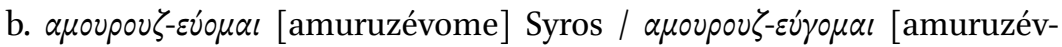
rome] Naxos

'be in love'

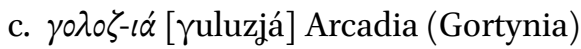

'gluttony'

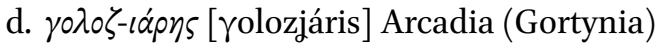

'glutton'

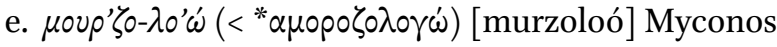

'be in love'

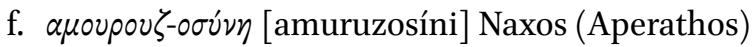
'courtship'

As regards semantics, the recipient varieties seem to have preserved one of the meanings of the donor language, maintaining the same connotations. In some cases the [-inanimate] referent of the donor language changes to [+animate] in the recipient varieties. For example, the Ven. petitoso 'causing appetite' was adopted in Corfu with the meaning 'person selective as regards food'.

\section{$5 \quad$ New Formations in MGr Dialects, Stems, and Constraints}

\subsection{New Formations in -ózos}

In the corpus we examined, there occur nineteen (19) new dialectal forms in -ózos. ${ }^{10}$ Meyer was the first to note, in 1895 , the productivity of the suffix -ózos in MGr dialects (see Meyer 1895: 100). Because there is no other chronological

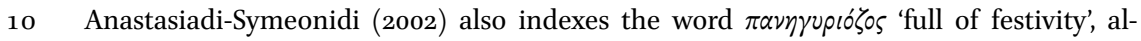


evidence, the end of the 19th c. and in particular the year 1895 offers a terminus ante quem for the first appearance of the words dealt with in the previous section. As Rainer (2015: 1777) notes, during the first step complex words are borrowed and during the second the pattern for new formations is extracted language-internally from the borrowed words. ${ }^{11}$ In our case, the first loanwords in -ózos were borrowed some time after the 13 th $\mathrm{c}$. and the first new formations are attested six centuries later.

$\operatorname{Six}(6)$ of these new formations give the impression that they are Venetian or Italian loanwords, although corresponding forms are not to be found in these putative donor languages. Such formations are:

(20) a. $\mu \varepsilon \tau \zeta o \sigma \tau \alpha \gamma \varkappa l-o ́ \zeta o s$ [metzostajózos] 'of an intermediate situation' Paxoi $(<$ $\mu \varepsilon \tau \zeta \circ \sigma \tau \alpha \gamma \varkappa i o ́(v)$ 'intermediate sistuation' < Ven. mezzostagion)

b. $\sigma \varepsilon \sigma \tau-\hat{o} \zeta o \varsigma$ [sestózos] 'orderly, regular, well-dressed' Corfu (< $\sigma \varepsilon \dot{\sigma} \sigma \tau$ 'elegance, care' < Ital. sesto)

c. $\sigma x \alpha \mu \pi-\delta ́ \zeta o s$ [skabózos] 'of good appearance' Cephalonia $(<\sigma x \alpha \dot{\alpha} \mu \pi \alpha$ 'appearance' < back formation of the verb $\sigma x \alpha \mu \pi i \zeta \omega$ 'see, descry' which is probably connected with $\sigma \propto \alpha \mu \pi \alpha \dot{\zeta} \zeta \omega$ 'see, understand' < Hellenistic $\sigma x \alpha \mu \beta a ́ \zeta \omega)$

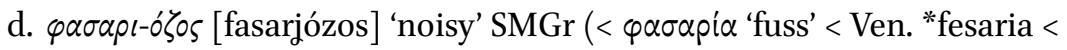
It. fesseria)

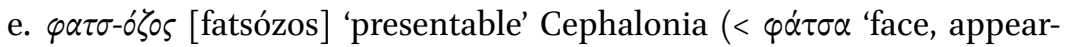
ance' < Ital. faccia).

The sixth member of this group is the adjective $\mu \pi$ ovyl-ó̧os [bujózos] 'bulky, impressive. The adjective derives from the loanword $\mu \pi$ oú 10 [bújo], which according to Babiniotis Dictionary $\left(2012^{4}\right)$ and Triantafyllidis Dictionary $\left(2007^{7}\right)^{12}$ derives from It. buio 'darkness'. This etymology does not satisfy the semantic criterion. On the other hand, current research has shown that the word comes from the Ven. noun bogio (Boerio 1856)/ bojo (Pizzati 2007) [bójo], meaning 'boiling, puff' (cf. also Ven. boger / bogir / bugir 'to boil' and bujio

though we did not find it in any MGr dialect. This word must be derived from the noun

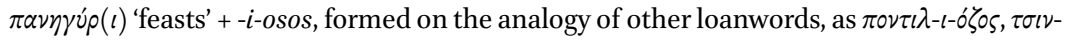

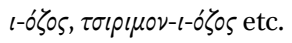

11 In terms of Haspelmath's temporal interpretation of Thomason \& Kaufman's scale of borrowing, elements from the first category (content words, for instance) are borrowed before elements from the second category (function words, minor phonological features, lexical semantic features) (Haspelmath 2008: 6). 
'boiled'). The loanword was adopted in MGr dialects as a neuter noun under the form $\mu \pi$ ớ 10 , meaning 'inflation, bulk' (Ithaca, Kythira, Leukada, Paxoi).

\subsection{New Formations in -ózos from Greek Nominal Stems}

In addition to the examples above, new adjectives derived from the addition of the suffix -ózos to Greek nominal stems of feminine nouns in $-a$ or $-i$ were located:

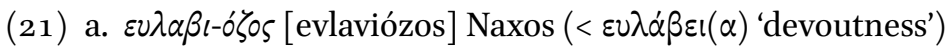
'devout'

b. $\pi \circ \mu \pi$-ó̧os [pobózos] Kythira $(<\pi \circ \mu \pi(\dot{\eta})$ 'debasement') 'arrogant, noisy'

Some of these new formations are based on the stem of masculine nouns in $-o s$, such as

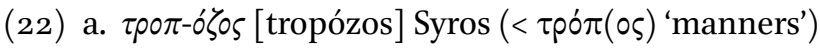

'well-mannered'

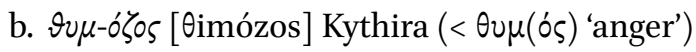

'very angry'

Others are based on the stem of neuter nouns in $-i$ or $-m a$ :

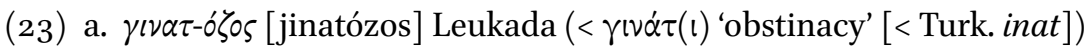
'willful or done with obstinacy'

b. $\sigma \omega \mu \alpha \tau-o ́ \zeta o s$ [somatózos] Paros, Naxos, Myconos, Cephalonia, Kythira (< $\left.\sigma \omega \dot{\omega} \mu \alpha \tau(\circ \varsigma)_{\mathrm{Gen}}\right)$

'stout'

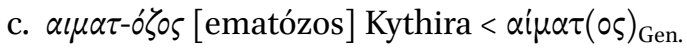
'full of blood, carmine'

For further information on the new formations in -ózos, see Index II 1-19.

In some of these cases, the formation derives from the translation of the bor-

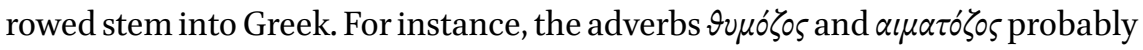
followed the pattern of the Ven./Ital. rabbioso and sanguioso respectively, in which the stems rabbi (a) 'anger' and sangue 'blood' are translated in Greek (cf. Anastasiadi-Symeonidi 2009: 64).

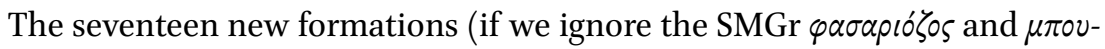
y'ó 05 ) are found mostly in the varieties current in the Ionian Islands and the Cyclades, where the criterion of Thomason \& Kaufman's scale (1988: 74-75) is 
TABLE 2 Geographical distribution of 19 new formations in -ózos

\begin{tabular}{lc} 
Place & $\begin{array}{c}\text { New formations } \\
\text { (total 19) }\end{array}$ \\
\hline Ionia & 1 \\
Ionian islands & 12 \\
Corinthos & 1 \\
Cyclades & 4 \\
Focida & 1 \\
\hline
\end{tabular}

valid. That is, the more borrowed categories a recipient language displays, the more intense the contact it has had with the donor language. In these particular varieties, the degree of exposure to the source language and the intensity of the language contact are especially high and consequently, if one leaves aside the very high number of borrowed content words, there is a large number of function words, ${ }^{13}$ the presence of which accounts both for the productivity of -ózos formations and for the occurrence of the suffix itself (see Table 2).

The morphological segmentation of the Italian/ Venetian loanwords into stem and suffix that gave birth to the these new formations was triggered by several factors, namely:

a) the large number of loanwords in -ózos and the existence of certain pairs of loanwords with and without the morpheme (Weinreich 19682: 31-37; see also Anastasiadi-Symenonidi 1994: 69-70). For example, both (24a) and (24b) coexist in Kythira:

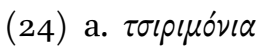
'excessive politeness'

b. $\tau \sigma i p \iota \mu o v i o ́ \zeta o s$ 'excessively polite'

13 For instance, in the Heptanesian dialects a large number of function words is attested (i.e.

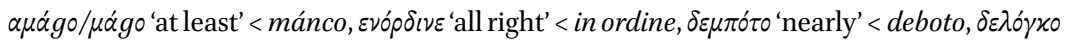
'immediately' $<$ delongo etc.) and many productive suffixes (i.e., - $\alpha \dot{\delta} \alpha<-a d a$, -ivo $<-i n o,-o ́ v l$ $<-o n e,-i p \omega<-i r(e),-\alpha \dot{p} \omega<-a r(e)$ etc.). 
and both $(25 \mathrm{a})$ and $(25 \mathrm{~b})$ coexist in Corfu and Paxoi:

(25) a. $\pi 0 v \tau i \lambda 10$

'obstinacy'

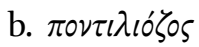

'willful'

These pairs make such structures transparent for the speaker, allowing him to identify a derivational morpheme in terms of loanwords, to analyze it, and later, when the morpheme becomes productive, to use it in the formation of new words (cf. Moravcsik 1978, Gómez Capuz 1997: 85, Field 2002: 38, Johanson 2002, Aikhenvald 2007: 33), ${ }^{14}$

b) the semantic autonomy that, according to Moravcsik (1978), Field (2002) and Johanson (2002), facilitates the borrowing process. The segmentation of loanwords into stems makes it easy for speakers to extract the core meaning of the suffix 'who/that has/presents a quantity or quality $\mathrm{x}$ when $\mathrm{x}$ is what the nominal stem expresses' (Magni 2001: 12-13), and

c) the stem-based nature of Greek morphology, in that words consist of a bound element (cf. Ralli 2012).

\subsection{Constraints on the Derivation of New Formations in -ózos}

The suffix -ózos in the examples in all of the new formations given immediately above is added to nominal stems. ${ }^{15}$ On these grounds, Meyer's (1895: 100) etymology of $\varepsilon v \lambda \alpha \beta i \sigma_{\zeta} \circ s$, which traces the word from the adjective $\varepsilon v \lambda \alpha \beta \eta^{\prime} s$ ('devout'), is to be rejected. In any case, Meyer's suggestion cannot explain the presence of [i] before the suffix. In fact, the word derives from the noun $\varepsilon v \lambda \dot{\alpha} \beta \varepsilon \iota \alpha$ 'devoutness'.

The case of $\sigma \omega \mu \alpha \tau$ 'ó ${ }_{0}$ makes it clear that new formations obey one main morphological constraint on the recipient language, that is, that the suffix -ózos is added only to the augmented allomorph of nouns in -ma. Thus we find

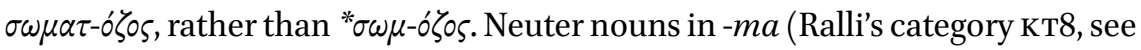

14 See also Anastasiadi-Symenonidi (1985: 91) on the productivity of the derivational loan suffix -e and Ralli (2012) on the productivity of the loan suffix -áro. Both argue that the coexistence of the suffixes with other etymological relative loanwords in the recipient language triggered the segmentation of the loanwords into stems.

15 On constraints on derivation, see Ralli (2005: 154: 157). 
Ralli 2005: 121) possess two allomorphs, ending in - $m a$ and -mat-, although only the second can participate in derivational and compositional processes.

Another significant point is that the specific suffixation process in MGr does not obey the constraint of the distinguishing lexical features of the stems. The suffix -ózos shows a preference for both stems of foreign origin (Italian, Venetian, Turkish) (see Index II 3, 6, 7, 9, 11, 15, 17, 18, 19) and native Greek stems (see also Index II 1, 2, 4, 5, 8, 10, 14, 16).

The reason why this suffixation became productive in the MGr dialects may spring from the fact that the suffixes - $\omega \delta \delta \varsigma$ (i.e. $\sigma \omega \mu \alpha \tau \omega \delta \delta \varsigma^{\prime}$ 'stout', $\vartheta \nu \mu \omega \dot{\delta} \eta \varsigma^{\prime}$ 'very

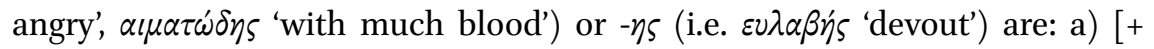
learned], b) display morphological irregularities in the formation of certain cases of the singular and plural, leading even native speakers to produce erro-

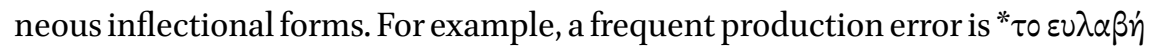

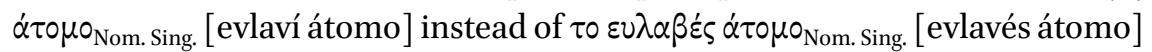

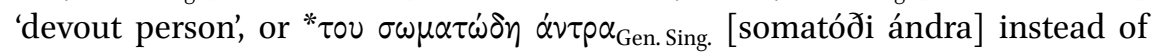

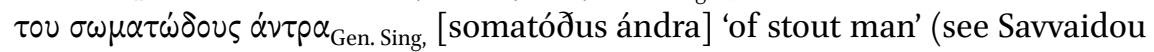
2012), c) do not discriminate the masculine from the feminine forms, i.e., $\sigma \omega \mu \alpha-$

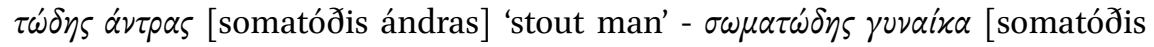
jinéka] 'stout woman' (cf. Anastasiadi-Symeonidi 1985: 100-101). ${ }^{16}$

This innovative suffixation process was thus not facilitated by the presence of any words already existing in the recipient language, which of course means that Aronoff's blocking constraint (1976:43-44) still stands. Non-Standard MGr dialects drew on alternative strategies that arose from the various historical and sociolinguistic conditions that shaped these dialects in order to deal with the inflectional difficulties inherent in the unwieldy learned - $\omega \delta \delta$ s suffix. SMGr, on the other hand, which had less intense contact with Romance languages, had a much greater tolerance for items of learned origin and a conversely lower tolerance for borrowed words, a situation that did clearly not promote the spread of the -ózos suffix.

Lastly, one notes that the core meaning of the loan suffix is maintained in the most derivatives in -ózos. The new formations express, in either a positive or pejorative manner, that somebody or something has the quality or quan-

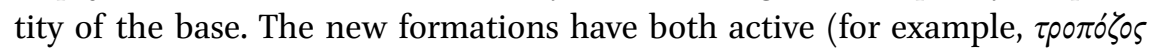

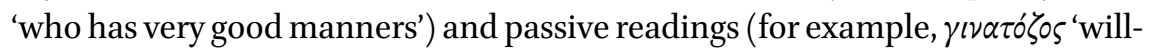
ful or done with obstinacy'), while the referent is mostly animate ( $\varepsilon \cup \lambda \alpha \beta 10 \zeta_{05}$

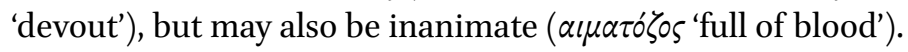

16 Anastasiadi-Symeonidi (1985:100-101)'s explanation of the establishment of the the suffix $-e$ in Koine Greek employs the same argument. 
Adjectives in -ózos in SMGr are very few. Indeed, there are just ten (10) such

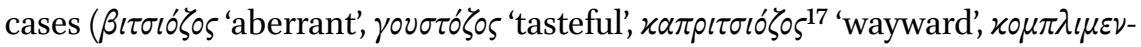

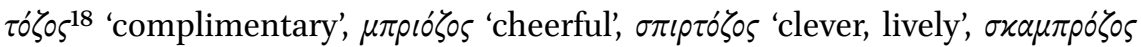

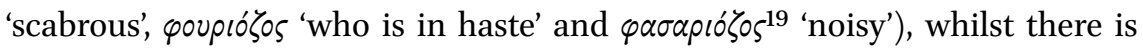

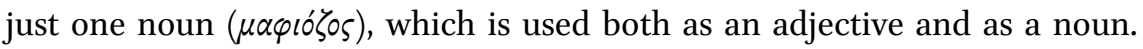
Attestations for these words are offered in both SMGr dictionaries (Babiniotis Dictionary $2012^{4}$, Triantafyllidis Dictionary $2007^{7}$, and Anastasiadi-Symeonidi Reverse Dictionary 2002) and in electronic corpora (ILSP, SEK, POTHEG). Their ability to form secondary formations (-ózos vs. -ózikos) has been statistically examined, though the intuitions of individual speakers regarding each particular lexical item may vary, thus slightly affecting the validity of conclusions drawn from these statistics. Of these, nine are loanwords and just one ( $\varphi \alpha \sigma \alpha-$ pró Yos) is actually a new formation. All the adjectives and the one noun in -ózos in SMGr refer mainly to animate referents. Furthermore, both adjectives and

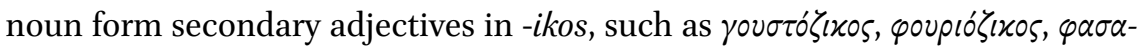

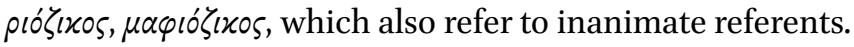

The case of the borrowed suffix -ózos is not unique. Since contact between Greek and Latin and other Romance languages was so intense, several suffixes forming adjectives were adopted by Greek (SMG and MGdialects), such as

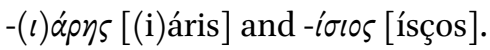

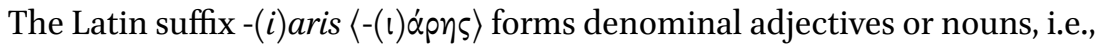

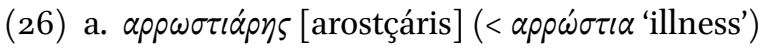

'sickly'

b. $x \lambda \alpha \psi i a ́ p \eta s$ [klapsçáris] (< $x \lambda \alpha \dot{\psi} \psi \alpha$ 'cry')

'sniveling; crybaby'

Its nominal base belongs to the nouns referring to illness, external imperfections, or some derogatory entity or external property. This suffix creates adjec-

\footnotetext{
17 This adjective is not lemmatized in Babiniotis' dictionary.

18 This adjective is not lemmatized in Triantafyllidis' dictionary.

19 This adjective is not lemmatized in Triantafyllidis' dictionary.
} 
tives expressing a permanent relationship of possession between the noun

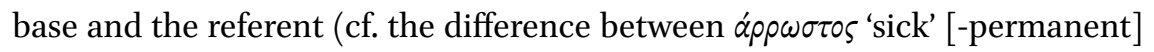

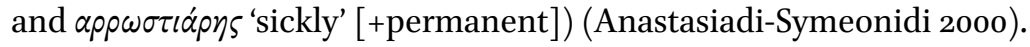

The post-Classical suffix -ísios $\langle-i \sigma 10 \varsigma\rangle$ is also of Latin origin. It derives from the Late Latin suffix -ēsis (< Lat. -ēnsis). It is also combined with nominal stems forming [-learned] denominal adjectives, such as:

(27) $x \alpha \mu \pi-i \sigma 10 \varsigma<x \alpha \dot{\mu} \mu \pi(0 \varsigma)$ 'plain'

'of the plain'

that possess the general meaning 'who/ what derives from $\mathrm{x}$ or associates with $\mathrm{X}$ ', when $\mathrm{X}$ is what the nominal stem expresses (Anastasiadi-Symeonidi 2009).

A comparison of these suffixes with -ózos makes it clear that the borrowing was triggered by the influx of a large, possibly even massive, number of loanwords in -ózos, -(i)áris and -ísios, where the core meaning of the suffixes is extractable. Their absorption into Greek was also aided by the borrowing, at the same time, of their noun base, which made the point of contact between stem and suffix clearly visible (cf. Anastasiadi-Symeonidi 2009: 63-64; see also above in 5.1), as in, for example,

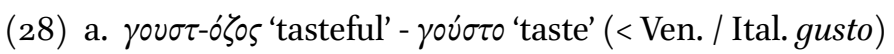

b. $x \alpha \mu \pi-i \sigma 10 \varsigma^{\prime}$ 'of the plain' - $x \alpha$ á $\mu \pi \circ$ 'plain' (< Lat. campus)

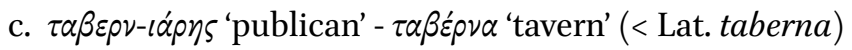

Furthermore, some of the new formations in -ózos and -isios arose from the translation of the noun base, with which the suffix was then combined (Anastasiadi-Symeonidi 2009: 64; see also above in 5.1), e.g.,

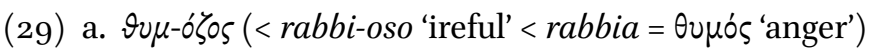
'ireful'

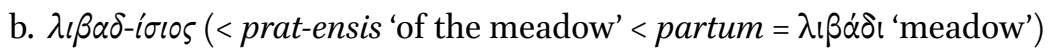
'of the meadow'

All three suffixes are [-learned] and are also combined with [-learned] noun bases. Adjectives (or nouns) in -ózos, -(i)áris, and -ísios are not used in academic or learned terminology and can be expected to occur in informal speech and in colloquial registers. The above suffixes form [-learned] adjectives in -ózos and -isios which display a variant [+learned] adjective from the same stems or from a synonym [+learned] stem constructed with another suffix (cf. AnastasiadiSymeonidi 2000: 65-66, Anastasiadi-Symeonidi 2009: 68-69). Examples are: 


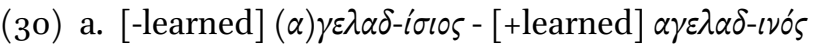
'of a cow'

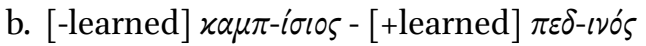
'of a plain'

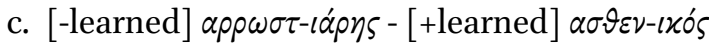
'sickly'

d. [-learned] $\sigma \omega \mu \alpha \tau-\sigma \zeta \zeta o \varsigma ~-~[+l e a r n e d] ~ \sigma \omega \mu \alpha \tau-\omega ́ \delta \eta \varsigma$ 'stout'

Nevertheless, the presence of these three suffixes has not led to the loss of any other competitive suffixes, as happened, for instance, in the case of the Middle English suffix -able, borrowed from Old French -able. Here, in the view of Trips \& Stein (2008), the influence of Old French limited or wiped out the native English suffixes -lice and -báre (see also Trips 2014: 404-406; cf. Scherer 2015: 1785). In fact, in terms of type frequency (Scherer 2015: 1783), the suffix -ózos is not as productive as -(i)aris and -isios in SMGr, although, in the view of Anastasiadi-Symeonidi (2009: 69-70), even the suffix -isios is apparently retreating today in SMGr, in the face of other competitive suffixes (-ivos, -i $i \tau \tau$ ixos, -ı́́⿱一兀)

To conclude, it is clearly the case that in the borrowing process of all three [-learned] suffixes, even if they were borrowed at different times, the same conditions applied. Initially complete lexical items, set in a transparent structure, were borrowed, although subsequently the suffix was detached and combined with other stems, to create new forms.

8 Conclusions

The suffix -ózos was adopted into Greek via the adoption of Venetian and Italian loanwords. Such words must have come into Greek after the 13th c., and how they were accommodated depended on the properties of the recipient language. Examples from many regions throughout Greece have been identified, but most are to be found in the Ionian Islands and the Cyclades, where there was intense contact with the donor languages. In these dialectal varieties, the loan suffix was fairly productive, as a significant number of new adjectives, whether positive or pejorative, testify. The new formations, however, were derived only from nominal stems from both foreign and native origin and retained the core meaning of the loan suffix.

In general, the history of suffix -ózos in Greek, when seen in comparison with those of the [-learned] suffixes -(i)áris and -ísios, confirms recent linguistic 
theories concerning the mechanisms of loan suffixation. We have also shown that the intensity of contact and the structural similarity between source and target language are of crucial importance to the process of lexical borrowing and that lexical and suffixal borrowing precedes grammatical borrowing. We have also shown that the path that the process of borrowing is usually assumed to follow is indeed correct, that is, that it does indeed consist of a progress from the adoption of whole lexical items consisting of transparent constituents (stem and suffix) via the detaching of the loan suffix, to the acquisition of the ability to combine with native stems.

\section{References}

Academy of Athens. 1933-1989. Istorikon Lexikon tis Neas Ellinikis (tis te koinis omiloumenis kai ton idiomaton), 5 vol. (A-daktylotos) [Historical Dictionary of Modern Greek]. Athens: Ekdoseis Hestia. [= ILNE] [In Greek]

Ahn, Geun-Jong. 1994. Dérivation des adjectifs suffixes par-eux:sens et rôles thématiques. Thèse de Doctorat. Université Paris X.

Aikhenvald, Alexandra Y. 2007. Grammars in contact: a cross-linguistic perspective. In Alexandra Y. Aikhenvald and Robert M.W. Dixon (eds.), Grammars in contact: A cross-linguistic typology, 1-66. New York: Oxford University Press.

Anastasiadi-Symeonidi, Anna. 1985. -é: ena neo epithima sti Ne [-é: A new suffix in MG]. Studies for the Greek Language 5: 89-110. [In Greek]

Anastasiadi-Symeonidi, Anna. 1994. Neologikos daneismos tis Neoellinikis [Neological Borrowing in Modern Greek]. Thessaloniki. [In Greek]

Anastasiadi-Symeonidi, Anna. 200o. To epithima -(i)áris sti Neoelliniki. [The suffix -(i)áris in Modern Greek]. Studies for the Greek Language 20: 65-74. [In Greek]

Anastasiadi-Symeonidi, Anna. 2002. Antistrofo Lexiko tis Neas Ellinikis [Reverse Dictionary of Modern Greek.] Thessaloniki: Institute of Modern Greek Studies (Manolis Triantafyllidis Foundation) at Aristotle University of Thessaloniki. [In Greek]

Anastasiadi-Symeonidi, Anna. 2009. To epithima -isi(os) sti Nea Ellikiki. [The suffix -isi(os) in Modern Greek] Studies for the Greek Language 29: 53-73. [In Greek]

Aronoff, Mark. 1976. Word Formation in Generative Grammar (Linguistic Inquiry Monograph No. 1). Cambridge: MIT Press.

Babiniotis, Georgios. 2012 ${ }^{4}$. Lexiko tis Neas Ellinikis Glossas [Dictionary of the Modern Greek Language]. Athens: Centre of Lexicology. [In Greek]

Boerio, Giuseppe. 1856. Dizionario del dialetto veneziano. Venezia: Tipografia di Giovanni Cecchini.

Browning, Robert. 1999. Medieval and Modern Greek. Cambridge: Cambridge University Press. 
Byzantios, Stephanos. $1874^{3}$. Lexikon tis kath' imas Ellinikis Dialektou methirmeneumenis eis to arxaion kai to gallikon [Dictionary of the modern Greek Dialect interpreted in ancient Greek and French]. Third edition, augmented and corrected. Athens: Andreas Koromilas.

Corominas, Juan. 1970. Diccionario critico etimologico de la lengua Castellana, 1-4 vol. Berna: Editorial Francke.

Cortelazzo Manlio. \& Paolo Zolli (eds). 1999². Il nuovo etimologico. DELI - Dizionario Etimologico della lingual Italinana. Second edizione in volume unico. Bologna: Zanichelli.

Cortelazzo, Manlio. 2007. Dizionario Veneziano della lingua e della cultura popola nel XVI secolo. Padova: La Linea Editrice.

Davy, Jim and Anna Panayotou. 200o. French loans in Cypriot Greek. In Yannis Ioannou, Françoise Métral and Marguerite Yon (eds.), Chypre et la Méditerranée orientale. Actes du Colloque tenu à Lyon, 1997, Université Lumière-Lyon 2, Université de Chypre (Travaux de la Maison de l' Orient Méditerranéen n ${ }^{\circ}$ 31), 2000, 113-125. Lyon: Maison de l' Orient Méditerranéen - Paris: De Boccard.

Ernout, Alfred. 1949. Le adjectives latins en -osus e en -ulentus. Paris: Klincksieck.

Field, Fredric. 2002. Linguistic Borrowing in Bilingual Contexts. Amsterdam: John Benjamins.

Fanciullo, Franco. 2008: Gli italianismi del neogreco. L'Italia Dialettale 69: 1-41.

Gómez Capuz, Juan. 1997. Towards a Typological Classification of Linguistic Borrowing (Illustrated with Anglicisms in Romance Languages). Revista Alicantina de Estudios Ingleses 10: 81-94.

Haspelmath, Martin. 2008. Loanword typology: Steps toward a systematic cross-linguistic study of lexical borrowability. In Thomas Stolz, Dik Bakker and Rosa Salas Palomo (eds.), Aspects of language contact: New theoretical, methodological and empirical findings with special focus on Romancisation processes, 43-62. Berlin: Mouton de Gruyter.

Holton, David and Io Manolessou. 2010. Medieval and Early Modern Greek. In Egbert J. Bakker (ed.), A Companion to the Ancient Greek Language, 539-563. Oxford: Blackwell.

Horrocks, Geoffrey. 2010. Greek: A History of the Language and its Speakers (revised and expanded 2nd edition). Oxford: Wiley-Blackwell.

Johanson, Lars. 2002. Structural Factors in Turkish Language Contacts. Richmond: Routledge - Curzon.

Idryma M. Triantafyllidis [M. Triantafyllidis Foundation]. 2007². Lexiko tis Koinis Neoellinikis [Dictionary of Standard Modern Greek]. Aristotle University of Thessaloniki: Institute of Modern Greek Studies. [In Greek]

ILNE, see Academy of Athens 1933-1989.

Katsouda, Georgia. 2012. I etymologisi se dialektika glossaria \& lexica: paradeigmata 
apo to kythiraiko idioma. [The etymology in dialectal glossaries and dictionaries: examples from the dialect of Kythira]. In Zoi Gavriilidou, Aggeliki Efthymiou, Evaggelia Thomadaki and Penelope Kambakis-Vougiouklis (eds.), Selected Papers of the 1oth International Conference of Greek Linguistics, 853-86o. Komotini, University of Komotini. [http://www.icgl.gr/files/greek/81-853-86o.pdf]

Kontoglou, Fotis. 2012. Adamasti psychi [Indomitable soul]. Athens: Agyra. [In Greek]

Kramer, Johannes. 1998. Von der 'Lex Wackernagel' zur 'Lex Clarysse'. Zur Akzentuierung der Latinismen in Griechischen. Zeitschrift für Papyrologie und Epigraphik 123: 129-134.

Kriaras, E. 1969-. Lexiko tis Mesaionikis Ellinikis Dimodous Logotexnias (110o-1669) [Dictionary of the Medieval Vulgar Greek Literature (1100-1669)]. Thessaloniki: Centre for the Greek Language.

Lass, Roger. 1999. The Cambridge History of the English Language. Volume III (14761776). Cambridge: Cambridge University Press.

Leontsinis, Georgios. 2005. Zitimata Heptanisiakis koinonikis historias [Issues of Heptanesian social history]. Athens: Tolidis. [In Greek]

Lehmann, Manu. $1977^{5}$. Lateinische Laut- und Formenlehre. München: Beck.

Magni, Elisabetta. 2001. Questioni di semantica nella mopfologia derivazionale dell' italiano: il suffisso -oso fra sincronia e diacronia. Archivio Glottologico Italiano 86: 3-24.

Maltezou, Chrysa. 2008. Ta Kythira ton kairo pou kyriarxousan oi Venetoi [Kythira when Venetians were ruling]. Venice: Hellenic Institute for Byzantine and Post-Byzantine Studies in Venice. [In Greek]

Manolessou, Io. 2008. Glossikes epafes ston elliniko mesaiona: i antonymia o opoios [Language contact in the Greek Middle Ages: The pronoun o opoios]. In Amalia Moser, Ekaterini Bakakou-Orfanou, Christoforos Charalambakis and Despina ChilaMarkopoulou (eds.), Glossis Charin [For the sake of language], 255-266. Athens: Ellinika Grammata. [In Greek]

Markopoulos, Theodoros. 2012. Language contact in the Middle Ages. Rhodes under the Hospitallers. In Zoi Gavriilidou, Aggeliki Efthymiou, Evaggelia Thomadaki and Penelope Kambakis-Vougiouklis (eds.), Selected Papers of the 1oth International Conference of Greek Linguistics, 425-431. Komotini: University of Komotini. [www.icgl.gr/ files/English/35.Markopoulos_10ICGL_pp.425-431.pdf]

Markopoulos, Theodoros. 2014. Language contact in the Byzantine world. Facts and ideologies. In Caterina Carpinato and Olga Tribulato (eds.) Storia e storie della lingua greca. Antichistica 5. Filologia e letteratura 1, 73-98. Venezia: Ca' Foscari.

McMahon, April. 1994. Understanding language change. Cambridge: Cambridge University Press.

Meillet, Antoine. 1921. Linguistique historique et linguistique générale. Paris: Klincksieck. Meyer, Gustav. 1895. Neugriechische Studien IV. Die romanischen Lehnworte im Neu- 
griechischen. Sitzungsberichte der Kais. Akademie der Wissenschaften in Wien. Philosophisch-Historische Classe, Bd. cxxxı. Wien: In commission bei F. Tempsky Miller, Gary D. 2012. Latin Suffixal Derivatives in English and their Indo-European Ancestry. Oxford: Oxford University Press.

Moisiadis, Theodoros. 2005. Etymologia. Eisagogi sti mesaioniki kai neoelliniki etymologia. [Etymology. Introduction to medieval and modern Greek etymology] Athens: Ellinika Grammata.

Montermini, Fabio. 2001. The unitary base hypothesis and the semantics of wordformation rules. In Pierrette Bouillon \& Kyoko Kanzaki (eds.), First international workshop on generative approaches to the lexicon (April 26-28, 2001, Geneva), 26-28. Genève: École de Traduction et d'interprétation.

Moravcsik, Edith. 1978. Universals of Language Contact. In Joseph H. Greenberg, Charles A. Ferguson and Edith A. Moravcsik (eds.), Universals of human language, vol. 1 Method and Theory, 93-122. Stanford, CA: Stanford University Press.

Peridis, M. 1878. Dicionario Greco-Italiano. Vol. A. Athens.

Pharies, David. 2015. The origin of suffixes in Romance. In Peter O. Müller, Ingeborg Ohnheiser, Susan Olsen and Franz Rainer (eds.), Word-Formation: An International Handbook of the Languages of Europe, vol. 3, 1854-1866. Berlin: de Gruyter.

Pizzati, Lodovico. 2007. Venetian-English. English-Venetian. When in Venice do as the Venetians. Bloomington - Milton Keynes: Author House.

Prieto Prieto, Rocío. 2002. La sufijación como procedimiento de formación de palabras en judeoespañol. In María Teresa Echenique Elizondo, Juan P. Sánchez Méndez and F. Javier Satorre Grau (eds.), Actas del $v$ Congreso Internacional de Historia de la Lengua Española, Valencia, 31 de enero-4 de febrero de 2000, 1577-1582. Madrid: Gredos.

Ralli, Aggeliki. 2005. Morfologia. [Morphology]. Athens: Patakis.

Ralli, Aggeliki. 2011. Morphology in language contact: verbal loanblend formation in Asia Minor Greek (Aivaliot). In Thomas Stolz, Martine Vanhove, Hitomi Otsuka, and Aina Urdze (eds.), Morphologies in contact. (Studia Typoloigica), 185-201. Berlin: Akademie Verlag.

Ralli, Aggeliki. 2012. Verbal loanblends in Griko and Heptanesian: a case study of contact morphology. L'Italia Dialettale LXXIII: 111-132.

Rainer, Franz. 2015. Mechanisms and motives of change in word-formation. In Peter O. Müller, Ingeborg Ohnheiser, Susan Olsen and Franz Rainer (eds.), Word-Formation: An International Handbook of the Languages of Europe, vol. 3, 1761-1781. Berlin: de Gruyter.

Rohlfs, Gerhard. 1969. Grammatica storica della lingua italiana e dei suoi dialetti. Torino: Einaudi.

Savvaidou, Paraskevi. 2012. Glossika lathi se lexikes monades se logia klisi: I periptosi ton epitheton se -is, -is, -es [Language errors in lexical units of learnt inflection: the 
case of the adjectives in -is, -is, -e]. In Proceedings of the 6th Postgraduate Conference of the Faculty of Philology (Nation and Kapodistrian University of Athens, 13-15 May 2011), vol. A, 278-287. Athens. [In Greek]

Savvidis, Alexios. 2003. Latinocracy - Francocracy after 1024 a.C. - identical terms? Byzantiaka 23: 187-209. [In Greek]

Scalise, Sergio. 1994. Morfologia. Bologna: Il Mulino.

Scherer, Carmen. 2015. Change in productivity. In Peter O. Müller, Ingeborg Ohnheiser, Susan Olsen and Franz Rainer (eds.), Word-Formation: An International Handbook of the Languages of Europe, vol. 3, 1781-1793. Berlin: de Gruyter.

Tekavčić, Pavao. 1980. Grammatica storica dell' italiano vol. 3. Lessico. Bologna: Il Mulino.

Terkourafi, Marina. 2005. Understanding the present through the past. Processes of koineisation in Cyprus. Diachronica 22 (2): 309-372.

Thomason, Sarah Grey and Terrence Kaufman. 1988. Language Contact, Creolization and Genetic Linguistics. Berkeley: University of California Press.

Trapp, Erich. 1994-. Lexikon zur byzantinischen Gräzität besonders des 9.-12. Jahrhunderts. Wien: Verlag der Österreichischen Akademie der Wissenschaften.

Triantafyllidis Dictionary, see Idryma M. Triantafyllidis [M. Triantafyllidis Foundation] $2007^{7}$.

Trips, Carola. 2014. Derivation and historical change. In Rochelle Lieber and Pavol Štekauer (eds.), The Oxford Handbook of derivational Morphology, 384-406. Oxford: Oxford University Press.

Trips, Carola \& Achim Stein. 2008. Was Old French -able borrowable? A diachronic study of word-formation processes due to language contact. In Richard Dury, Maurizio Gotti \& Marina Dossena (eds.), English Historical Linguistics 2006: Selected papers from the fourteenth International Conference on English Historical Linguistics (ICE HL 14), Bergamo, 21-25 August 2006. Volume II: Lexical and Semantic Change, 217239. Amsterdam: John Benjamins.

Weinreich, Uriel. 1968². Languages in Contact (1st edn. 1953). The Hague: Mouton.

\section{Electronic Addresses}

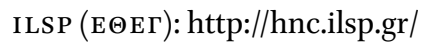

POTHEG (ПОЄЕГ): http://www.potheg.gr/

Online etymology dictionary: http://www.etymonline.com/

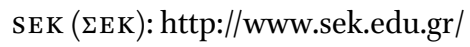




\section{Index (see ILNE and Archive of KENDI-ILNE)}

I

\begin{tabular}{lllll}
\hline $\begin{array}{l}\text { Loanwords } \\
\text { in recipient }\end{array}$ & Forms & Place & Meaning & Donor language \\
language & & & \\
\hline
\end{tabular}

(a) After the 13th century

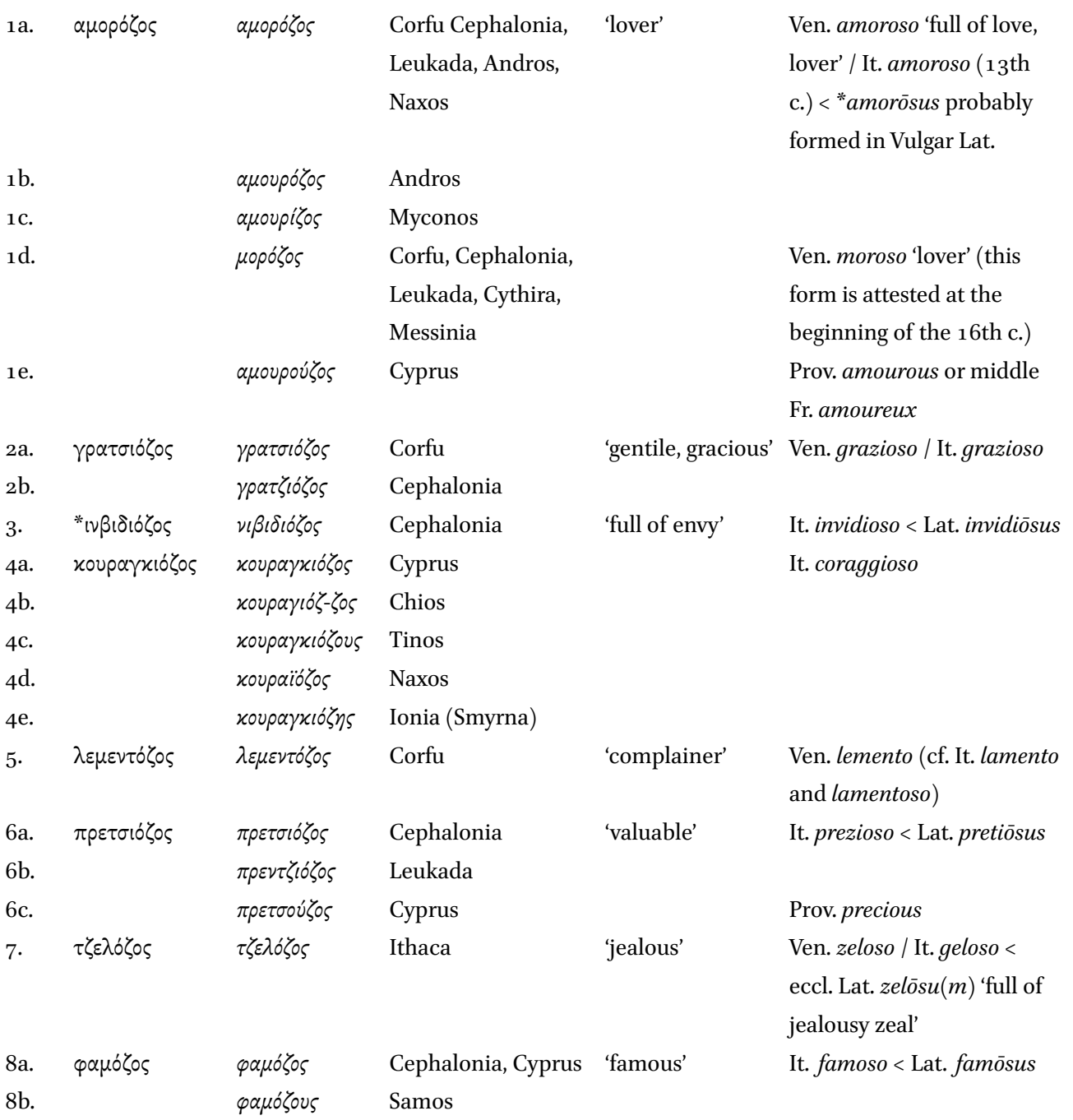




\begin{tabular}{|c|c|c|c|c|c|}
\hline & $\begin{array}{l}\text { Loanwords } \\
\text { in recipient } \\
\text { language }\end{array}$ & Forms & Place & Meaning & Donor language \\
\hline 9a. & youplółos & youpió̧os & SMGr & 'who is in haste' & $\begin{array}{l}\text { It. furioso 'full of haste or } \\
\text { rage' < Lat. furiōsus }\end{array}$ \\
\hline gb. & & youpióyous & $\begin{array}{l}\text { Tinos, Ioannina, } \\
\text { Etoloakarnania }\end{array}$ & & \\
\hline 9c. & & 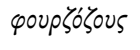 & Lemnos & & \\
\hline gd. & & youpółos & Achaia & & \\
\hline ge. & & 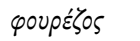 & Mani & & \\
\hline
\end{tabular}

(b) After the 14th century

\begin{tabular}{|c|c|c|c|c|c|}
\hline 1. & $\beta \alpha \lambda \varepsilon \rho o ́ \zeta o \varsigma$ & 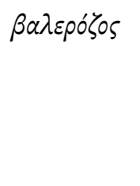 & Cephalonia & 'worthy, capable' & $\begin{array}{l}\text { It. valoroso. } \\
\text { The dialectal Greek form } \\
\text { was probably influenced by } \\
\text { the It. valerusso }\left(15^{\text {th }} \text { c. }\right)\end{array}$ \\
\hline 2. & 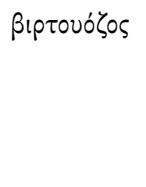 & Bıpтovó̧os & $\begin{array}{l}\text { SMGr and in many } \\
\text { MGr dialects }\end{array}$ & 'skillfull' & $\begin{array}{l}\text { Ven. virtuoso / It. virtuoso } \\
\text { (the meaning appeared } \\
\text { during the Cinquecento)< } \\
\text { Lat. virtuōsus 'virtuous' }\end{array}$ \\
\hline 3. & 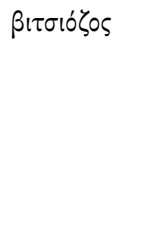 & $\beta ı \tau \sigma i o ́ \zeta 0 s$ & $\begin{array}{l}\text { SMGr and in many } \\
\text { MGr dialects }\end{array}$ & 'aberrant' & $\begin{array}{l}\text { Ven. vizioso / It. vizioso } \\
\text { 'vicious, aberrant' (with this } \\
\text { meaning at the beginning } \\
\text { of the } 14 \text { th c.) < Lat. } \\
\text { vitiōsus. }\end{array}$ \\
\hline $4 a$. & roגó̧os & rodó̧os & $\begin{array}{l}\text { Cephalonia, Ithaca, } \\
\text { Cephalonia, Kea, } \\
\text { Crete, Myconos, } \\
\text { Syros, Euboia, } \\
\text { Preveza and } \\
\text { elsewhere }\end{array}$ & 'glutton' & $\begin{array}{l}\text { Ven. goloso 'tasty' / It. } \\
\text { goloso 'glutton' < Lat. } \\
\text { gulōsus. }\end{array}$ \\
\hline $4 \mathrm{~b}$. & & $\gamma^{\prime} \lambda o_{\text {Yous }}$ & Leukada & & \\
\hline $4 c$. & & 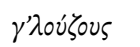 & Kythnos & & \\
\hline $4 \mathrm{~d}$. & & 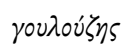 & Megara & & \\
\hline 5 a. & $\delta \varepsilon \sigma \pi \varepsilon \tau \tau^{\prime} \zeta \circ \varsigma$ & 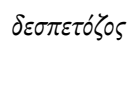 & Corfu, Cephalonia & $\begin{array}{l}\text { 'one who throws } \\
\text { tantrums' }\end{array}$ & Ven. despetoso \\
\hline $5 \mathrm{~b}$. & & 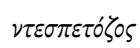 & Corfu & & \\
\hline
\end{tabular}


(cont.)

\begin{tabular}{|c|c|c|c|c|c|}
\hline & $\begin{array}{l}\text { Loanwords } \\
\text { in recipient } \\
\text { language }\end{array}$ & Forms & Place & Meaning & Donor language \\
\hline $5 c$. & & $\delta, \sigma \pi \varepsilon \tau \dot{\zeta} \zeta 0 \varsigma$ & Corfu & & It. dispetoso \\
\hline $6 a$. & xoupló\}os & xovpró̧os & $\begin{array}{l}\text { Cephalonia, Paxoi, } \\
\text { Andros, Kythira, } \\
\text { Mani }\end{array}$ & curious & $\begin{array}{l}\text { Ven. curioso / It. curioso } \\
\text { (with the meaning 'who } \\
\text { wants to know' at the } \\
\text { end of the } 14 \text { th c.) < Lat. } \\
\text { curiōsus 'who cares' }\end{array}$ \\
\hline $6 \mathrm{~b}$. & & xopló̧os & Leukada, Bithynia, & & \\
\hline $6 c$. & & xoupló̧ous & $\begin{array}{l}\text { Tinos, Samos, } \\
\text { Chalcidice }\end{array}$ & & \\
\hline $6 \mathrm{~d}$. & & xouploú̧ous & Euboia & & \\
\hline $6 e$ & & xovpvółos & Hpeiros & & \\
\hline $6 f$ & & xopvió̧os & Cyprus & & \\
\hline $6 g$. & & oxopió̧os & Propontida & & \\
\hline 7. & $\mu 1 \rho \alpha x \circ \lambda o ́ \zeta o s$ & $\mu \iota p a x o \lambda o ́ \zeta 0 s$ & Corfu, Cephalonia & 'miraculous' & $\begin{array}{l}\text { It. miracoloso < Mediev. Lat. } \\
\text { miraculōsus }\end{array}$ \\
\hline $8 a$. & $\pi \varepsilon p$ w $о \lambda$ ó $о \varsigma$ & $\pi \varepsilon p i x \circ \lambda o ́ \zeta 0 s$ & Cephalonia, Kythira & $\begin{array}{l}\text { 'dangerous, full } \\
\text { of danger' }\end{array}$ & $\begin{array}{l}\text { Ven. pericoloso / It. } \\
\text { pericoloso }\end{array}$ \\
\hline $8 \mathrm{~b}$. & & $\pi \varepsilon \rho(x \circ) \lambda o ́ \zeta o s$ & Cephalonia & & $\begin{array}{l}\text { It. periculoso < Lat. } \\
\text { periculōsus }\end{array}$ \\
\hline 9. & $\pi \varepsilon p \nu i \tau \sigma i o ́ \zeta o s$ & $\pi \varepsilon \rho v i \tau \sigma i o ́ \zeta 0 s$ & Corfu & 'dangerous' & $\begin{array}{l}\text { It. pernicioso < Lat. } \\
\text { perniciōsus }\end{array}$ \\
\hline 10. & 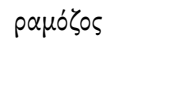 & рано́̆оs & Cyprus & $\begin{array}{l}\text { 'possessing } \\
\text { many branches' }\end{array}$ & It. ramoso \\
\hline $11 \mathrm{a}$. & $\sigma x \alpha \mu \pi \rho \sigma^{\prime} \zeta{ }^{\prime}$ & $\sigma x \alpha \mu \pi \rho \circ \zeta_{0 \varsigma}$ & SMGr & $\begin{array}{l}\text { 'who socks in a } \\
\text { cute way' }\end{array}$ & $\begin{array}{l}\text { It. scabroso < Late Lat. } \\
\text { scabrōsus }\end{array}$ \\
\hline $11 \mathrm{~b}$. & & & Cephalonia & $\begin{array}{l}\text { 'tough, difficult, } \\
\text { irregular' }\end{array}$ & \\
\hline $11 \mathrm{c}$. & & $\sigma x о \mu \pi \rho o ́ \zeta o s$ & Cephalonia, Milos & $\begin{array}{l}\text { 'tough, difficult, } \\
\text { irregular' }\end{array}$ & \\
\hline
\end{tabular}




\begin{tabular}{|c|c|c|c|c|c|}
\hline & $\begin{array}{l}\text { Loanwords } \\
\text { in recipient } \\
\text { language }\end{array}$ & Forms & Place & Meaning & Donor language \\
\hline $12 \mathrm{a}$. & $\varphi \lambda \alpha \tau o ́ \zeta \circ \varsigma$ & 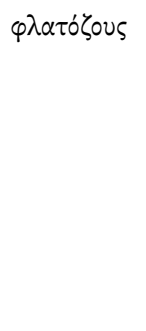 & Etoloakarnania & $\begin{array}{l}\text { "ill because of a } \\
\text { chronic disease/ } \\
\text { sometimes bad } \\
\text { sometimes } \\
\text { well" Cf. } \\
\varphi \lambda \text { d́tos Kythnos } \\
\text { 'bellyache' }\end{array}$ & Ven. flatoso 'causing gases' \\
\hline $12 \mathrm{~b}$. & & $\varphi \lambda \lambda a \tau o v o ́ \zeta o s$ & $\begin{array}{l}\text { Byzantios } \\
\text { Dictionary }\left(1874^{3} \text { : }\right. \\
576)\end{array}$ & $\begin{array}{l}\text { 'for a food, } \\
\text { causing gases' }\end{array}$ & < It. flatuoso \\
\hline
\end{tabular}

(c) After the 15th century

\begin{tabular}{|c|c|c|c|c|c|}
\hline $\begin{array}{l}1 . \\
2 a .\end{array}$ & 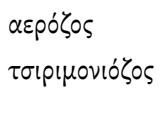 & 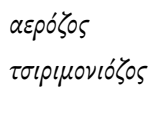 & $\begin{array}{l}\text { Kythira } \\
\text { Kythira, Peridis }\end{array}$ & 'full of air' & $\begin{array}{l}\text { It. aeroso } \\
\text { It. cerimonioso }\end{array}$ \\
\hline $2 b$. & & $\tau \sigma i p \mu o v i o ́ \zeta o s$ & Andros & 'excessively kind' & \\
\hline
\end{tabular}

\section{(d) After 16th century}

\begin{tabular}{|c|c|c|c|c|c|}
\hline $1 \mathrm{a}$. & 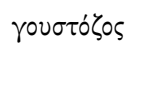 & 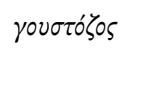 & SMGr & $\begin{array}{l}\text { 'tasteful, stylish, } \\
\text { funny' }\end{array}$ & Ven. gustoso / It. gustoso \\
\hline $1 b$. & & 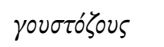 & northern dialects & & \\
\hline $1 \mathrm{c}$. & & 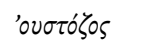 & Naxos & & \\
\hline $2 a$. & 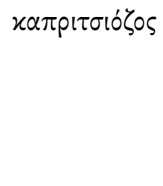 & 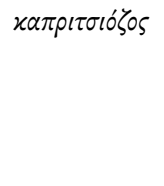 & $\begin{array}{l}\text { SMGr and in many } \\
\text { MGr dialects / }\end{array}$ & $\begin{array}{l}\text { 'who does } \\
\text { caprices/ which } \\
\text { is done with } \\
\text { caprices' }\end{array}$ & It. capriccioso \\
\hline $2 b$. & & $x \alpha \pi p i \tau \sigma o ́ \zeta o \varsigma$ & Crete & & \\
\hline $2 c$. & & 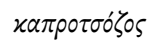 & West Crete & & \\
\hline 3 . & $\mu \pi$ pló̧os & $\mu \pi p l o ́ \zeta o s$ & $\begin{array}{l}\text { SMGr and in many } \\
\text { MGr dialects }\end{array}$ & 'cheerful' & It. brioso \\
\hline 4. & $\pi ı \tau \imath \tau o ́ \zeta o \varsigma$ & $\pi i \tau i \tau o ́ \zeta o s$ & Corfu & 'selective in food' & $\begin{array}{l}\text { Ven. petitoso (cf. appetitoso } \\
\text { 'causing the appetite'). }\end{array}$ \\
\hline
\end{tabular}


(cont.)

$\begin{array}{lllll}\text { Loanwords } & \text { Forms } & \text { Place } & \text { Meaning } & \text { Donor language } \\ \text { in recipient } & & & \\ \text { language } & & & \end{array}$

\begin{tabular}{|c|c|c|c|c|c|}
\hline 5. & 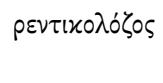 & 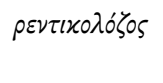 & Cephalonia, Kythira & 'ridiculous' & $\begin{array}{l}\text { Ven. rediculoso / It. } \\
\text { ridicoloso < Lat. ridiculōsus }\end{array}$ \\
\hline $6 a$. & $\sigma \pi i p i \tau o ́ \zeta o s$ & $\sigma \pi i p \imath \tau o ́ \zeta o s$ & Naxos & 'clever, lively' & $\begin{array}{l}\text { Ven. spiritoso / It. spiritoso } \\
\text { 'which contains alcohol/ } \\
\text { full of energy' }\end{array}$ \\
\hline $6 \mathrm{~b}$. & & $\sigma \pi i p \tau o ́ \zeta o s$ & SMGr & & \\
\hline $6 c$. & & 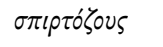 & Allonisos, Tinos & & \\
\hline $6 \mathrm{~d}$. & & $\sigma \pi i \rho \tau \sigma o ́ \zeta 0 \varsigma$ & Etoloacarnania & & \\
\hline
\end{tabular}

(e) After the 17th century

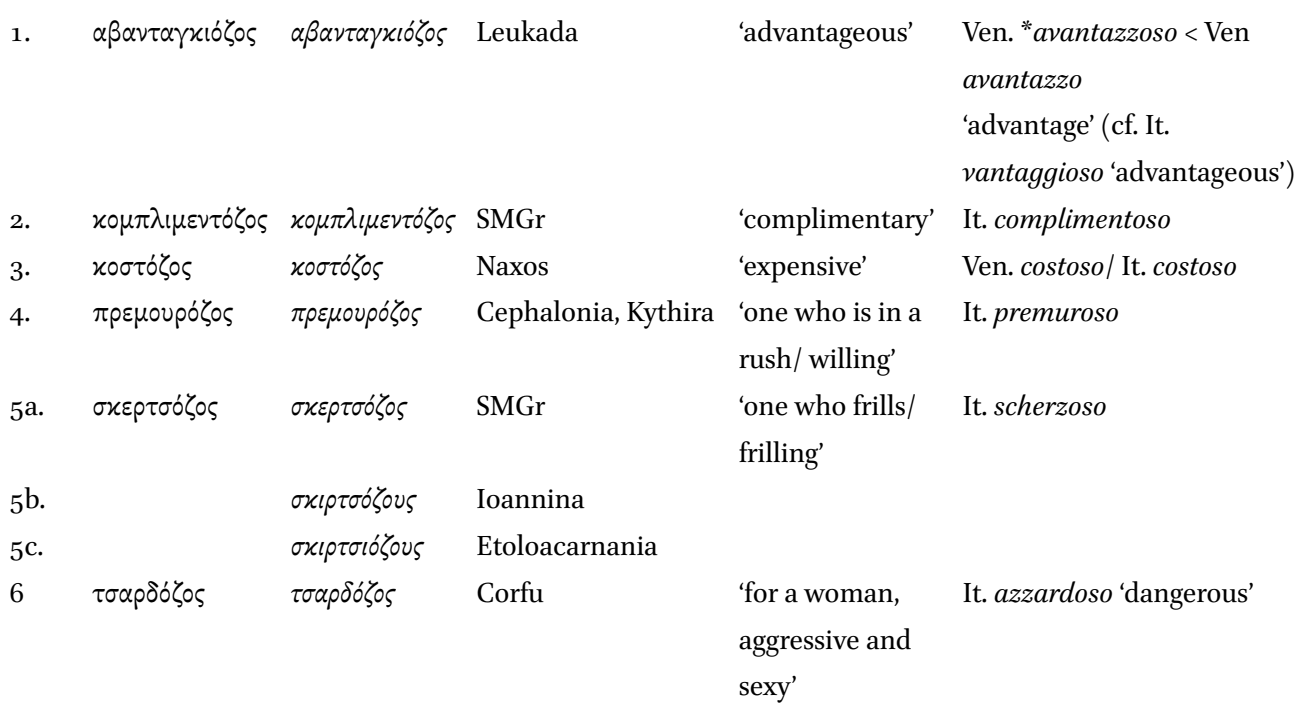

(f) After 18th century

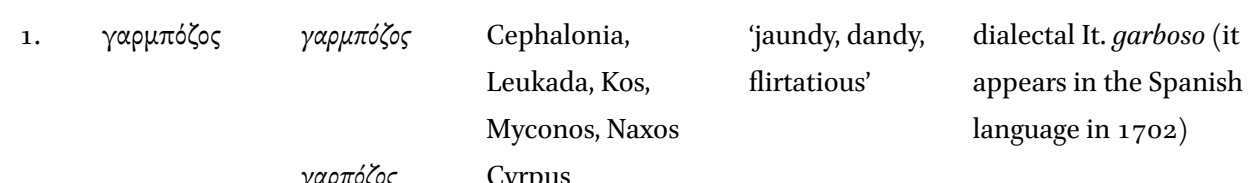

raprółos Cyrpus 


\begin{tabular}{|c|c|c|c|c|c|}
\hline & $\begin{array}{l}\text { Loanwords } \\
\text { in recipient } \\
\text { language }\end{array}$ & Forms & Place & Meaning & Donor language \\
\hline 2. & 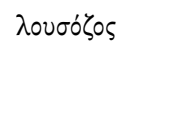 & 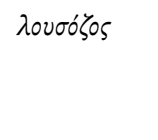 & $\begin{array}{l}\text { Corfu, Cephalonia, } \\
\text { Paxoi-Antipaxoi, } \\
\text { Messinia }\end{array}$ & $\begin{array}{l}\text { 'luxurious, } \\
\text { sprangly, dandy' }\end{array}$ & It. lussuoso \\
\hline за. & $\pi \circ v \tau i \lambda \iota_{1}{ }^{\prime} \zeta \circ \varsigma$ & $\pi 0 v \tau i \lambda l o ́ \zeta 05$ & $\begin{array}{l}\text { Cephalonia, Corfu, } \\
\text { Leukada, Paxoi }\end{array}$ & 'stubborn, nippy' & $\begin{array}{l}\text { Ven. pontiglioso (cf. It. } \\
\text { puntiglioso) }\end{array}$ \\
\hline $3 b$. & & $\pi 0 v \tau i \gamma i o ́ \zeta 0 \varsigma$ & Corfu & & \\
\hline 3c. & & $\pi 00 \nu \tau i \lambda l o ́ \zeta 05$ & Hpeiros & & \\
\hline $3 \mathrm{~d}$. & & $\pi \circ v \tau^{\prime} \lambda \iota o^{\prime} \zeta o \varsigma$ & Leukada & & \\
\hline
\end{tabular}

(g) After the 19th century

\begin{tabular}{|c|c|c|c|c|}
\hline 1. $\sigma \pi \varepsilon \tau \alpha x \circ \lambda \sigma^{\prime} \zeta \circ \varsigma$ & $\sigma \pi \varepsilon \tau \alpha x \circ \lambda o ́ \zeta o s$ & Cephalonia & 'imposing' & $\begin{array}{l}\text { Ven. spetacoloso / It. } \\
\text { spetacoloso 'spectacular' }\end{array}$ \\
\hline$\mu \alpha \varphi$ Ió̧os & $\mu \alpha \varphi$ 'о́ढ & SMGr & $\begin{array}{l}\text { 'member of the } \\
\text { mafia' }\end{array}$ & It. mafioso \\
\hline
\end{tabular}




\begin{tabular}{|c|c|c|c|c|c|}
\hline & $\begin{array}{l}\text { New formation } \\
\text { in recipient } \\
\text { language }\end{array}$ & $\begin{array}{l}\text { Other } \\
\text { forms }\end{array}$ & Place & Meaning & Derived from \\
\hline \multirow[t]{2}{*}{1.} & $\alpha \mu \mu \alpha \tau o ́ \zeta \circ \varsigma$ & & Kythira & $\begin{array}{l}\text { 'full of blood, } \\
\text { carmine' }\end{array}$ & $\alpha i \mu \alpha \tau(0 \varsigma)_{\text {Gen. }}$ 'blood' \\
\hline & & $\mu \alpha \tau o ́ \zeta o s$ & Leukada & & \\
\hline 2. & $\alpha \pi 0 x o v \tau p ı ́ \zeta o s$ & & Paros & 'hypochondriac' & aлoxovтpi( $\alpha$ ) 'hypocondria' \\
\hline 3 & 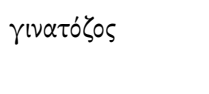 & & Leukada & 'obstinate' & $\begin{array}{l}\gamma \iota \nu \alpha \dot{\tau}(\iota) \text { 'obstinacy'< Turk. } \\
\text { ınat }\end{array}$ \\
\hline 4. & $\varepsilon \cup \lambda \alpha \beta 10 ́ \zeta \circ \varsigma$ & & Naxos & 'devout' & $\varepsilon v \lambda \alpha ́ \beta \varepsilon l(\alpha)$ 'devoutness' \\
\hline 5 . & 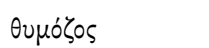 & & Kythira & 'very angry' & $\vartheta \nu \mu(o ́ \varsigma)$ 'anger' \\
\hline 6. & $\mu \varepsilon \tau \zeta \circ \sigma \tau \alpha \gamma \chi 10 ́ \zeta 0 \varsigma$ & & Paxoi & $\begin{array}{l}\text { 'of an intermediate } \\
\text { situation' }\end{array}$ & $\begin{array}{l}\mu \varepsilon \tau \zeta 0 \sigma \tau \alpha \gamma \varkappa i o ́(\nu) \text { 'intermidiate } \\
\text { sistuation'< Ven. } \\
\text { mezzostagion }\end{array}$ \\
\hline 7. & $\mu \pi$ ourió̧os & & SMGr & 'bulky, impressive' & $\begin{array}{l}\mu \pi \circ \gamma_{\gamma \iota(0)} \text { 'bulk'< Ven. bogio / } \\
\text { bojo }\end{array}$ \\
\hline \multirow[t]{2}{*}{8.} & $\mu v \tau \alpha \rho o ́ \zeta o \varsigma$ & & $\begin{array}{l}\text { Othonoi, Korinthos } \\
\text { (Feneos) }\end{array}$ & $\begin{array}{l}\text { 'one who has a big } \\
\text { nose' }\end{array}$ & $\mu v \tau \alpha ́ \rho(\alpha)$ 'big nose' \\
\hline & & $\mu^{\prime} \tau a p o ́ \zeta o u s$ & $\begin{array}{l}\text { Focida (Arachova, } \\
\text { Desphina) }\end{array}$ & & \\
\hline 9. & 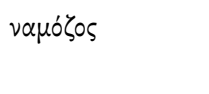 & & Ionia & 'famous' & $\begin{array}{l}\nu a ́ \mu(\iota) \text { 'reputation' < Turk. } \\
\text { nam }\end{array}$ \\
\hline 10 & $\pi \circ \mu \pi \dot{o} \zeta \circ \varsigma$ & & Kythira & 'arrogant, noisy' & $\pi \circ \mu \pi\left(\dot{\eta}^{\prime}\right)$ 'debasement' \\
\hline 11. & $\sigma \varepsilon \sigma \tau o ́ \zeta ం \varsigma$ & & Corfu & $\begin{array}{l}\text { 'orderly, regular, } \\
\text { well-dressed' }\end{array}$ & 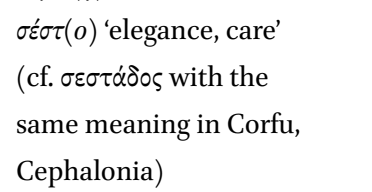 \\
\hline 12. & $\sigma x \alpha \mu \pi \delta ́ \zeta o s$ & & Cephalonia & $\begin{array}{l}\text { 'of good } \\
\text { appearance' }\end{array}$ & $\begin{array}{l}\sigma x \alpha \dot{\alpha} \mu \pi(\alpha) \text { 'flamboyant } \\
\text { appearance' < back formation } \\
\text { of the verb } \sigma \propto \alpha \mu \pi i \zeta \omega \text { 'see' }\end{array}$ \\
\hline 13. & $\sigma \omega \mu \alpha \tau o ́ \zeta o s$ & & $\begin{array}{l}\text { Paros, Naxos, } \\
\text { Myconos, } \\
\text { Cephalonia, Kythira }\end{array}$ & 'stout' & 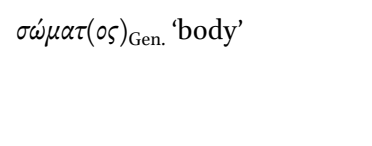 \\
\hline 14. & $\tau p \circ \pi \delta ́ \zeta o s$ & & Syros & $\begin{array}{l}\text { 'one who has very } \\
\text { good manners' }\end{array}$ & $\tau \rho o ́ \pi(0 \varsigma)$ 'manners' \\
\hline
\end{tabular}




\begin{tabular}{|c|c|c|c|c|c|}
\hline & $\begin{array}{l}\text { New formation } \\
\text { in recipient } \\
\text { language }\end{array}$ & $\begin{array}{l}\text { Other } \\
\text { forms }\end{array}$ & Place & Meaning & Derived from \\
\hline 15 . & $\tau \sigma \alpha \lambda \mu \mu o ́ \zeta \circ \varsigma$ & & Paxoi & $\begin{array}{l}\text { 'one who does airs } \\
\text { and graces or what } \\
\text { is done by airs and } \\
\text { graces' }\end{array}$ & $\begin{array}{l}\tau \sigma \alpha \lambda i \mu(\iota) \text { 'airs and graces' < } \\
\text { Turk. çalım }\end{array}$ \\
\hline 16. & 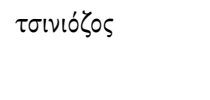 & & Cephalonia & 'willful' & $\begin{array}{l}\tau \sigma i v l(\alpha) \text { 'obstinacy' < } \tau \sigma \iota \nu \omega \text { ' to } \\
\text { kick' (cf. } \tau \sigma \iota \nu \alpha^{\prime} \text { 'kick') }\end{array}$ \\
\hline 17 . & $\chi \alpha \tau i \rho o ́ \zeta o s$ & & Kythira & $\begin{array}{l}\text { 'one who does } \\
\text { many favors' }\end{array}$ & 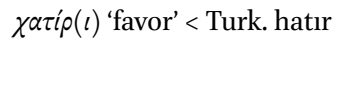 \\
\hline 18. & 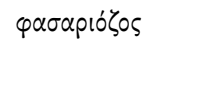 & & $\begin{array}{l}\text { SMGr and in many } \\
\text { MGr dialects }\end{array}$ & 'noisy' & $\begin{array}{l}\text { Ven. *fesaria < It. fesseria } \\
\text { 'fuss' }\end{array}$ \\
\hline 19 & $\varphi \alpha \tau \sigma o ́ \zeta o \varsigma$ & & Cephalonia & 'presentable' & $\begin{array}{l}\varphi \alpha ́ \tau \sigma \alpha \text { 'face, appearance' < It. } \\
\text { faccia }\end{array}$ \\
\hline
\end{tabular}

